\begin{tabular}{|c|c|c|}
\hline & 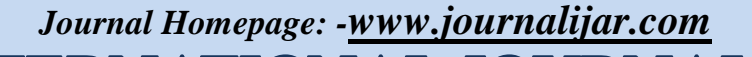 & $\begin{array}{l}\text { INTERNATIONAL JOURNAL OF } \\
\text { ADVANCED RESEARCH (IJAR) }\end{array}$ \\
\hline ISSN NO. 2320-5407 & $\begin{array}{c}\text { Article DOI:10.21474/IJAR01/8220 } \\
\text { DOI URL: http://dx.doi.org/10.21474/IJAR01/8220 }\end{array}$ & \\
\hline
\end{tabular}

RESEARCH ARTICLE

\title{
EVALUATION OF THE RESTORATION PROCESS OF A PLANTATION: CASE OF BENICHAB (MAURITANIA).
}

\author{
Ahmedou Soule ${ }^{1,2}$, AhmedouVadel Salihi ${ }^{2}$, Mohamed Mahmoud Abidine ${ }^{2}$, Mohamed Yahya Lafdal ${ }^{4}$, Pierre \\ Begat ${ }^{3}$ and Et Anthony Mills ${ }^{3}$. \\ 1. Ecole Normale Supérieure de Nouakchott/Centre de Recherche pour la Valorisation de la Biodiversité (CRVB). \\ 2. Unite de recherche Biodiversité et Valorisation des Ressources Végétales (BVRV). \\ 3. C4 EcoSolutions Climate Change and Environmental 9B Mohr Road, Tokai, 7945, Cape Town, South Africa. \\ 4. National Cell of Environmental Observation and Drylands (CNOZA) / MEDD.
}

\section{Manuscript Info}

\section{Manuscript History}

Received: 16 October 2018

Final Accepted: 18 November 2018

Published: December 2018

Key words:-

Survival rate, population structure, vegetation monitoring, aridity,

Mauritania

\section{Abstract}

This work is part of the research and knowledge management component of the Ecosystem-Based Adaptation (EBA) through SouthSouth cooperation project "Enhancing Capacity, Knowledge and Technology Support for Developing Climate Resilience of Vulnerable and Developing Countries", known as EBA SOUTH. It presents the main results of a study carried out on a plantation of several species, carried out in the arid zone of Benichab in Inchiri (Mauritania). To characterize the state of plantations, surveys were undertaken on randomly selected plots. The floristic and dendrometric characteristics of the species encountered were determined. The results show the ability of certain species to settle in hyper-arid conditions and the value of species selection during planting. They constitute a reference state that can be used as a basis for monitoring the dynamics of vegetation in this plantation.

Copy Right, IJAR, 2017,. All rights reserved.

\section{Introduction:-}

The village of Benichab in northern Mauritania is subject to a Saharan-type climate characterized by hot and dry winds that blow all year round. The effect of the wind is amplified by the absence of vegetation cover. Thus, the Benichab urban center project is highly threatened by the silting inherent in strong wind erosion. For this reason, the priority of the public authorities is to secure the dunes to protect the village ${ }^{[1]}$ against silting which threatens its existence and threatens the livelihoods (pastoralism, market gardening) of the populations.

It is in this context that the project entitled "Building capacities, knowledge and technology support for the climate resilience of vulnerable countries" has intervened in Benichab to restore 70 ha according to the ecosystem-based adaptation (EbA) approach.

In the past, reforestation actions aimed at protecting the city against silting have failed due to the harsh climate and inadequate restoration protocols. Added to this is the lack of protection against stray animals.

The purpose of this study is to evaluate the survival and growth of dryland planting in order to have reliable and measurable criteria for assessing plant quality for post-transplant recovery.

Corresponding Author:-Ahmedou Soule.

Address:-Ecole Normale Supérieure de Nouakchott/Centre de Recherche pour la Valorisation de la Biodiversité (CRVB). 


\section{Material AndMethods:-}

Study area:-

The city of Benichab is located in the north of the country (Fig. 1). It belongs administratively to the Moughataa of Akjoujt, Wilaya of Inchiri. It has the approximate coordinates $19^{\circ} 26^{\prime} \mathrm{N} \_15^{\circ} 21^{\prime} \mathrm{W}$.

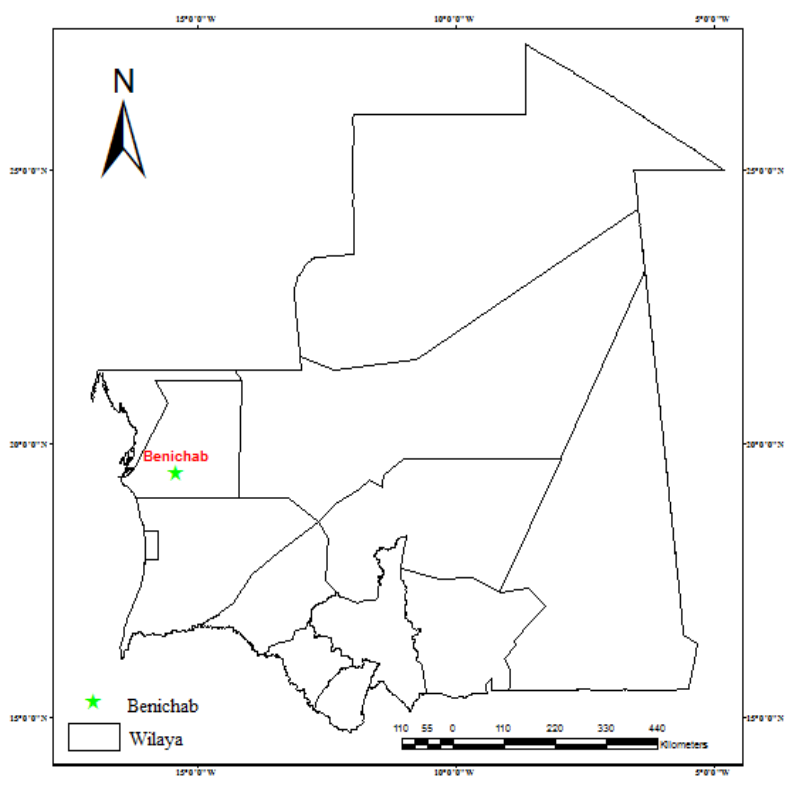

Figure 1:- Situation of the study area in mauritania

The Benichab site, subject of the study, has two subsites, A and B. Our study focuses on sub-siteA only. Referring to the only weather station in the Wilaya, located in Akjoujt since 1931, there is no real rainy season in the region (Fig. 2 ) because $P$ is less than $2 T$ during the whole year.

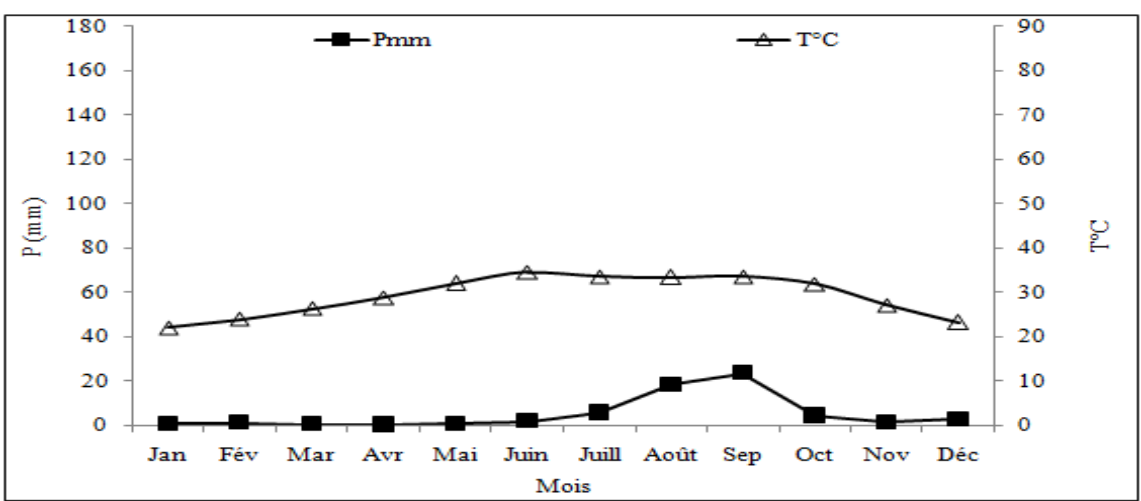

Figure 2:-Ombrothermal diagram of the Akjoujt station (National Office of Meteorology (ONM) data series 19602015).

The climate is dry all year long. Indeed, Benichab is subject to an arid climate of adesert type. Rainfall is rare and irregular (Fig. 3). Rainfall averages rarely exceed $150 \mathrm{~mm}$ per year.

The peak of rare rains is observed during the period August-September, or even a prolongation of exceptional rainfall until January, with the influence of the Mediterranean rains. The average annual rainfall is $58 \mathrm{~mm}$ at Akjoujt. It is very variable from one year to another. 


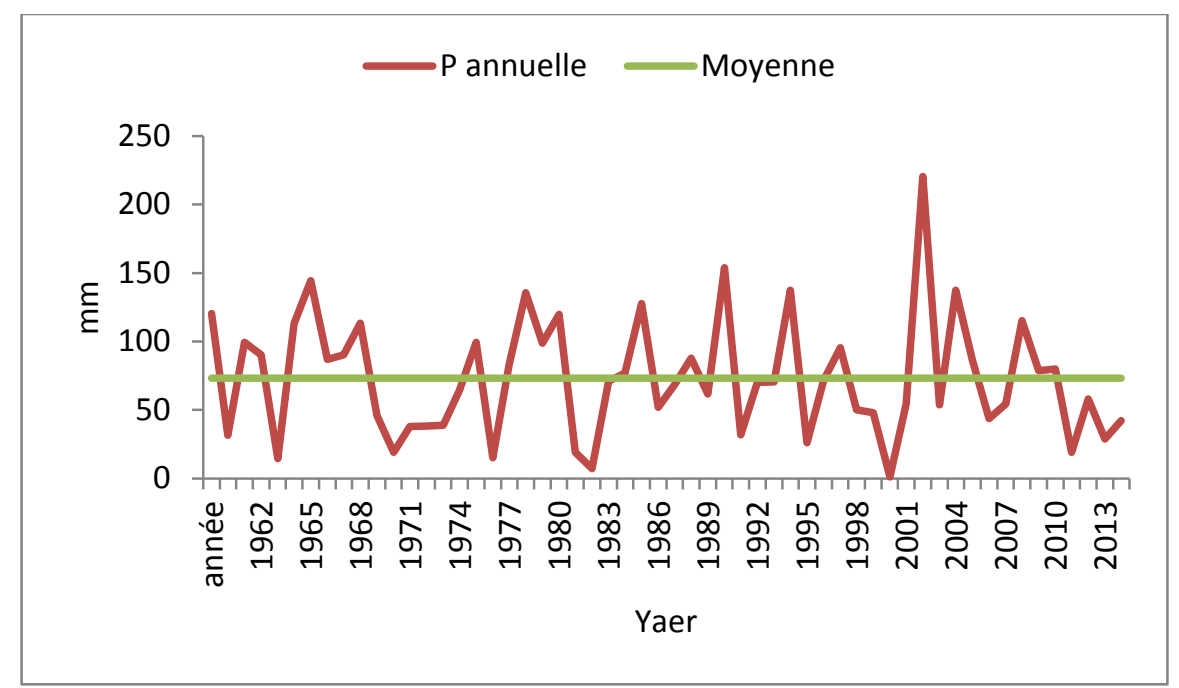

Figure 3:- Interannual variability of rainfall at Akjoujt (ONM data series 1960-2015)

The average monthly relative humidity recorded at the Akjoujt station ranges from around 30\% in May to $44 \%$ in August. It is on average $35.5 \%$. Benichab knows a thermal regime of continental type marked by high temperatures in summer. The annual average is of the order of $29.1^{\circ} \mathrm{C}$. The daily thermal amplitude is very strong.

The annual evaporation is $4949 \mathrm{~mm}$ at Akjoujt. The month with the highest evaporation is May (545 mm), and the month with the lowest evaporation is December $(335 \mathrm{~mm})$. Benichab is characterized by the frequency of constantly blowing winds. The prevailing winds are from North to North East.

Rainfall was in deficit in the last two years, when it was respectively $22 \mathrm{~mm}$ in 2016 and $35 \mathrm{~mm}$ in 2017 (source ONM), which greatly affected the survival, vigor and growth of seedlings.

The site on which our study was conducted is formed by a plantation with several species of $65.02 \mathrm{ha}$ (1042 $\mathrm{m} \mathrm{x}$ $624 \mathrm{~m})^{[1]}$. It is located east of the city of Benichab (fig.4).

\section{Sampling design:-}

The plots studied were set up from March 2016 using identical methods and techniques. Thus, all plants were nursed for a few months before being planted in sub-site A (Fig 4).

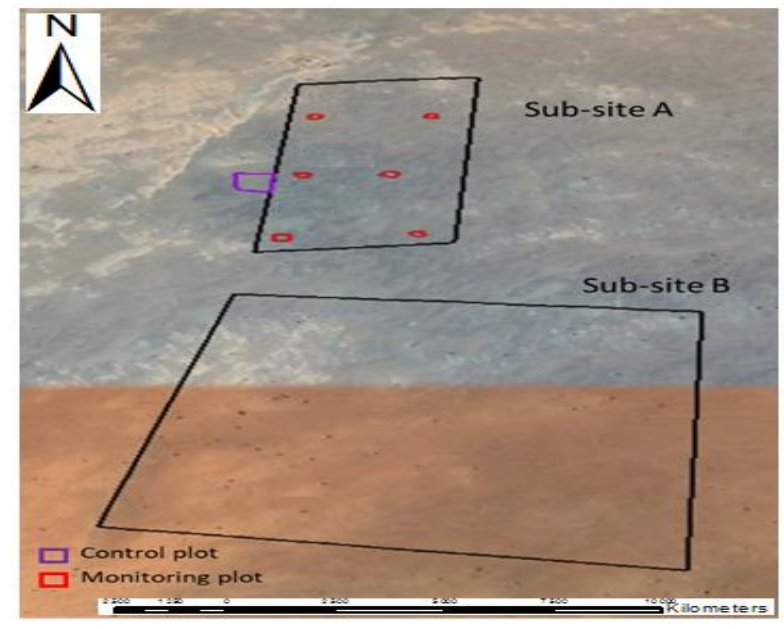

Figure 4:-Site map

In terms of maintenance and protection of plantations, very little has been done except to water and protection of plants against stray animals. The conditions of crop maintenance, far from being perfect, have however allowed the 
establishment of the plantation under severe conditions, more favorable than natural conditions to improve the resistance of young plants.

The quality of the plants at the time of transplanting is a major factor in the success and start-up of the plantations. Unfortunately, we do not have very precise data on the quality of the plants, the mode and frequency of their watering, or their age at the time of transplanting. Nevertheless, we assume that these factors were identical. Only two rows of Prosopis juliflora along the fence and serving as windbreaks benefited from a special watering (drip irrigation). As a result, they were not considered in this study.

\section{Data collection:-}

To characterize the state of the plantations in the site, the surveys were carried out on observation plots of $900 \mathrm{~m}^{2}$ $(30 \mathrm{mx} 30 \mathrm{~m})$. They are separated by $300 \mathrm{~m}$ in the direction of the length of the block and $200 \mathrm{~m}$ in width. Six sample plots were inventoried (Figure 4). In each plot, a comprehensive count of planted species was conducted.

For each living individual, the following parameters were measured:

1. The height of the stem, part between the collar and the highest point of vegetation, was measured using a tape measure.

2. The average height of the plants (ratio of the sum of heights and the number of live plants) is given by the formula $\mathrm{Hm}=\Sigma \mathrm{Hi} / \mathrm{Pv}^{[2]}$.

3. The diameter of the collar rod was measured using calipers.

4. The diameter of the crown is measured in both East-West and North-South directions using a tape measure.

5. The vigor of live plants was assessed through visual observation of the condition of the plants. When taking measurements in each parcel visited, a qualitative visual assessment of each plant was established according to three levels: high, medium or low vigor.

6. Knowing the interval between plants, one can easily determine dead individuals (visible dead, or absent where they should be) and many living individuals.

7. The survival rate of plants (Ts) was evaluated which was obtained by comparing the number of live plants (Pv) with the number of plants initially transplanted $(\mathrm{Nt})$, all multiplied by 100:Ts $=(\mathrm{Pv} / \mathrm{Nt}) \times 100($ Bekker et al., $2004)^{[3]}$.

Data analysis:-

The data collected was processed by the Microsoft EXCEL software to calculate structural parameters (basal area, cover, density, etc.).

The ecological characterization of the plants was carried out by evaluating the population structure of the plantation (in diameter and height), the total density, the basal area, the vigor and the survival rate of the species.

The basal area G, expressed in $\mathrm{m}^{2} /$ ha, is the surface density of the sum of the cross sections of the individuals: $\mathrm{G}=$ $\frac{\pi}{4 s} \sum_{I=1}^{n} d i^{2[4][5]}$

Where $\mathrm{n}$ is the number of individuals of each species in the plot, $\mathrm{S}$ is the area of the inventory plot (in $\mathrm{m}^{2}$ ), and di is the diameter of an individual i (in $\mathrm{mm}$ ).

\section{Results And Discussions:-}

Floristic diversity:-

The site consists of two rows of Prosopis juliflora on the periphery, along the fence, which constitute windbreaks watered drip.

Within the site, the main species that have been planted are Acacia tortilis, Prosopis juliflora and, incidentally, Balanites aegyptiaca and Acacia senegal. These are randomly arranged in blocks. Other species are represented by isolated individuals; this is the case of Moringa oleifera, Delonix regia, Ziziphus mauritiana, Terminalia catappa, Cajanus cajan, Pitecellebium dulce and Leucena leucocephalla.

In addition to these species planted in the site, the natural vegetation consists of a few feet of Maerua crassifolia, Capparis decidua and Acaia tortilis. 
The inventoried woody flora is rich in 13 species divided into 12 genera belonging to 6 families (Table 1). The Fabaceae occupy the first place with $38.5 \%$ of the inventoried species. Asclepiadaceae and Capparaceae have 2 species each. The other three families (Combretaceae, Rhamnaceae and Balanitaceae) have only one species each. Acacia tortilis is the most common species; it is present in all inventoried plots. Balanitesa egyptiaca and Prosopis juliflora are found in 17 and $50 \%$ of the surveys, respectively.

Acacia tortilis and Prosopis juliflora are the two most used species for reforestation. They alone account for nearly $95 \%$ of the reforested area.

Table 1:- Distribution of inventoried species

\begin{tabular}{|c|c|}
\hline Scientific name & Family \\
\hline Calotropis procera & \multirow[t]{2}{*}{ ASCLEPIADACEAE } \\
\hline Leptadenia pyrotechnica & \\
\hline Balanites aegyptiaca & BALANITACEAE \\
\hline Capparis decidua & \multirow[t]{2}{*}{ CAPPARACEAE } \\
\hline Maerua crassifolia & \\
\hline Terminalia catappa & COMBRETACEAE \\
\hline Acacia senegal & \multirow[t]{6}{*}{ FABACEAE } \\
\hline Acacia tortilis & \\
\hline Cajanus cajan & \\
\hline Delonix regia & \\
\hline Moringa oleifera & \\
\hline Prosopis juliflora & \\
\hline Ziziphus mauritiana & RHAMNACEAE \\
\hline
\end{tabular}

Characteristics of the plantations:-

The average values of the different measured dendrometric parameters (height, stem circumference, crown diameter), vigor and survival parameters were used to characterize the plantation and to estimate the ability of the species to adapt to the environment (Table 2).The following table shows dendrometric characteristics of the main species found at the study site.

Table 2:-Characteristics of the main species of the plantation

\begin{tabular}{|c|c|c|c|c|c|c|c|c|c|c|c|}
\hline \multirow[t]{2}{*}{ Species } & \multicolumn{2}{|c|}{ Vitality \% } & \multicolumn{3}{|c|}{ Vigor \% } & \multicolumn{2}{|c|}{ Height (cm) } & \multicolumn{2}{|c|}{$\begin{array}{l}\text { Neck } \\
\text { diameter (mm }\end{array}$} & \multicolumn{2}{|c|}{$\begin{array}{l}\text { Diameter of } \\
\text { the } \\
\text { crown }(\mathrm{cm})\end{array}$} \\
\hline & Death & $\begin{array}{c}\text { Livi } \\
\text { ng }\end{array}$ & High & $\begin{array}{c}\text { Avera } \\
\text { ge }\end{array}$ & Low & $\begin{array}{c}\text { Avera } \\
\text { ge }\end{array}$ & $\begin{array}{c}\text { Standar } \\
\mathrm{d} \\
\text { deviatio } \\
\mathrm{n}\end{array}$ & $\begin{array}{c}\text { Averag } \\
\mathrm{e}\end{array}$ & $\begin{array}{c}\text { Standar } \\
\mathrm{d} \\
\text { deviatio } \\
\mathrm{n}\end{array}$ & $\begin{array}{c}\text { Averag } \\
\mathrm{e}\end{array}$ & $\begin{array}{l}\text { Standar } \\
\text { d } \\
\text { deviati } \\
\text { on }\end{array}$ \\
\hline
\end{tabular}




\begin{tabular}{|l|c|c|c|c|c|c|c|c|c|c|c|}
\hline Acacia tortilis & 45.5 & 54.5 & 18 & 68.4 & 13.5 & 6.8 & {$[16.3]$} & 28.9 & {$[2,6]$} & 32.8 & {$[15.4]$} \\
\hline $\begin{array}{l}\text { Balanites aegyptia } \\
\text { ca }\end{array}$ & 61.5 & 38.5 & $\begin{array}{c}16 . \\
7\end{array}$ & - & 83.3 & 5 & {$[5,2]$} & 18.8 & {$[1]$} & - & \\
\hline Prosopis juliflora & 58.7 & 41.3 & $\begin{array}{c}44 . \\
4\end{array}$ & 18.5 & 37 & 7.1 & {$[22.1]$} & 48.6 & {$[2,5]$} & 39.1 & {$[16]$} \\
\hline Maerua crassifolia & - & - & - & 92.3 & 7.7 & 47.2 & {$[34.4]$} & - & & 42 & {$[33.6]$} \\
\hline Acacia senegal & & & $\begin{array}{c}18.6 \\
2\end{array}$ & 45.5 & 36.4 & 25.8 & {$[19.2]$} & 6.5 & {$[3]$} & 22.1 & {$[13.6]$} \\
\hline
\end{tabular}

\section{Plant survival rate:-}

In arid environments, the key factor in ensuring the establishment of a newly planted plant is proper watering because after planting, the available water in the rhizosphere is quickly depleted.

Newly planted plants require more maintenance than established plants ${ }^{[5]}$, they must be watered frequently and protected from animals to promote growth during the early stages of development.

In our experimental conditions, the average survival rate for the entire plantation is $54.5 \%$. However, there is a significant difference between species (Fig 5). The highest survival rate was observed in Prosopis juliflora (58.7\%), followed by Acacia tortilis (54.5\%) and Balanites aegyptiaca (38.5\%), respectively. Prosopi sjuliflora and Acacia tortilis do not show significant differences. It is important to note that plant survival is related to their vigor and environmental conditions at the time of and after planting. The slight superiority of Prosopis juliflora can be attributed to the high vigor of the plants at the time of planting. Indeed, the majority of planted Prosopis plants come from Nouakchott. They were more vigorous than those raised in nurseries locally because of the very difficult environmental conditions in Benichab. Italso benefited from maintenance and replenishment because of the availability of the plants.

Moreover, after planting, it has been noticed that the mortality of Ziziphus mauritiana plants is very high. All the plants are dead. This is why these dendrometric characteristics have not been studied. This high mortality confirms that this species, which is not native to the Benichab region, is not adapted to these conditions.

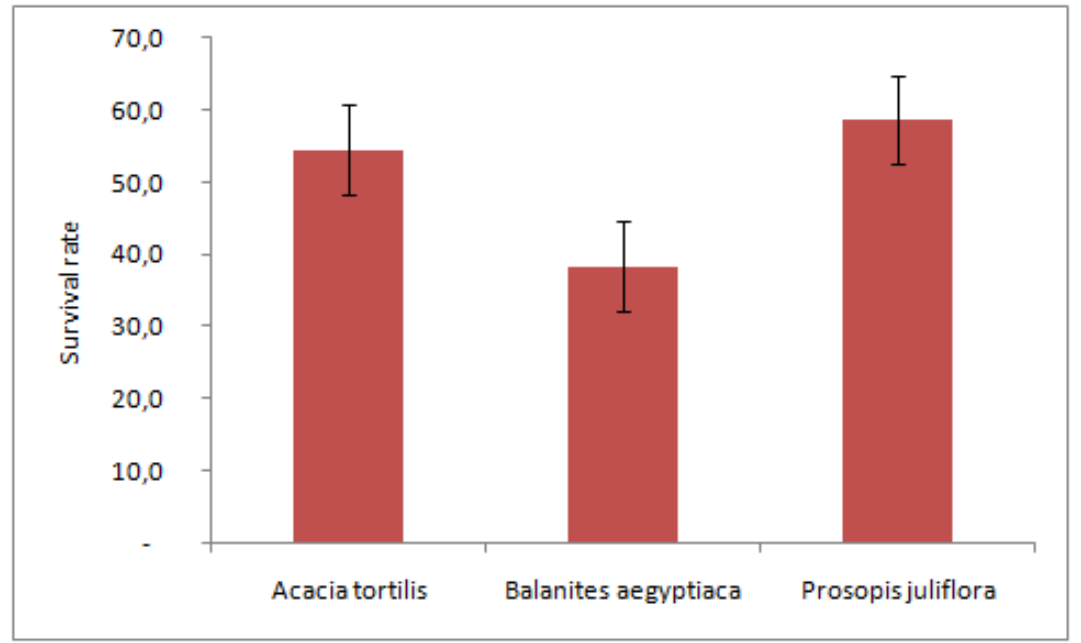

Figure 5:-Survival rate of main species

\section{Planting performance:-}

The performance of the plants is in fact the result of the confrontation of the qualities of the plants and the conditions of the environment at the time and after the planting ${ }^{[6]}$. 
The estimation of the quality of the plants is difficult to achieve. The condition of the plantations was observed for each plant according to three criteria: high, medium or low vigor. In general, according to the inventory data, nearly three-fifths of the plants have a weak vigor (58.8\%), particularly Balanites aegyptiaca, of which $80 \%$ of the plants are of low vigor. The other two most used tree species for reforestation, Acacia tortilis and Prosopis juliflora, show moderate to high vigor (Fig.6).

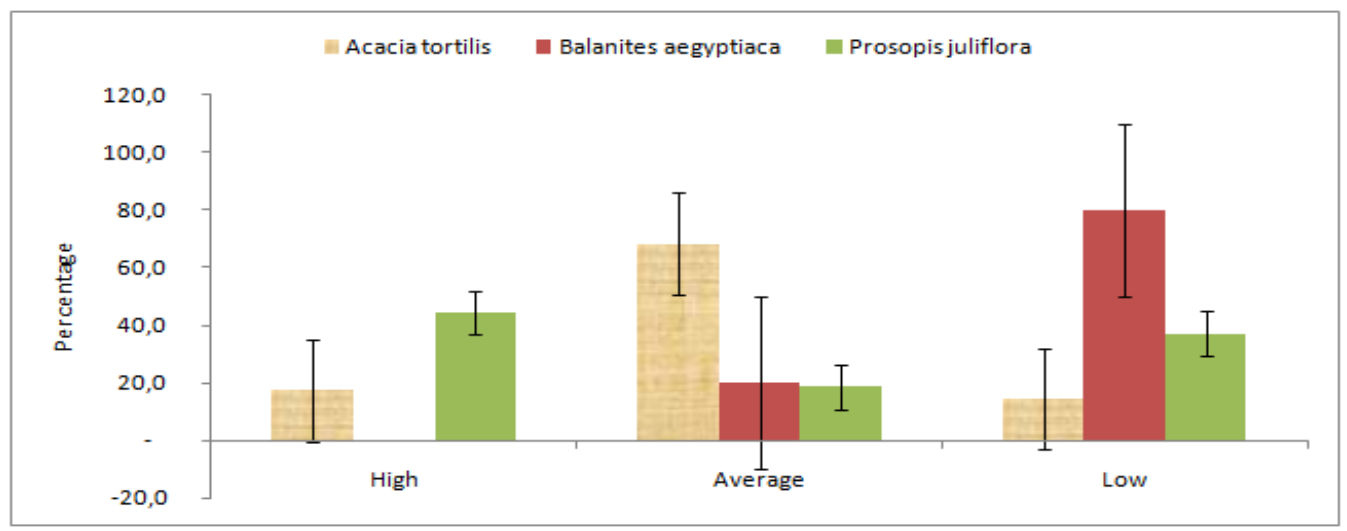

Figure 6:-Vigor of plantations

\section{Basal area:-}

The basal area of the plantation, that is, the sum of the basal areas of all the plants in it, provides a good evidenceof the density of the plantation. It is evaluated globally at $0.012 \mathrm{~m}^{2} /$ hawhich is variable according to the species. Table 3 shows the basal areas of the main species. Among these species, Acacia tortilis has the highest basal area $\left(0.01 \mathrm{~m}^{2}\right.$ / ha), which represents more than $82.6 \%$ of total basal area. But these figures are very low because of the youth of the plantation.

Table 3:-Mean basal area $\left(\mathrm{m}^{2} / \mathrm{ha}\right)$ of main species

\begin{tabular}{|l|l|}
\hline Species & Basal area $\mathbf{~ m}^{2} / \mathbf{h a}$ \\
\hline Acacia tortilis & 0.010 \\
\hline Balanitesaegyptiaca & 0.00019 \\
\hline Prosopisjuliflora & 0.0022 \\
\hline
\end{tabular}

\section{Structure:-}

\section{Distribution according to the height of the plants:-}

The distribution of plant numbers according to height is represented in Figure 7. The average height is $31.82 \mathrm{~cm}$. The plantation distribution is unimodal (mode $=10-20 \mathrm{~cm}$ ) and is better adapted to a polynomial curve of degree 6 . This curve represented a predominance of individuals whose height is less than or equal to $50 \mathrm{~cm}(88 \%)$. However, individuals with a height greater than or equal to $50 \mathrm{~cm}$ represent only $(12 \%)$. 


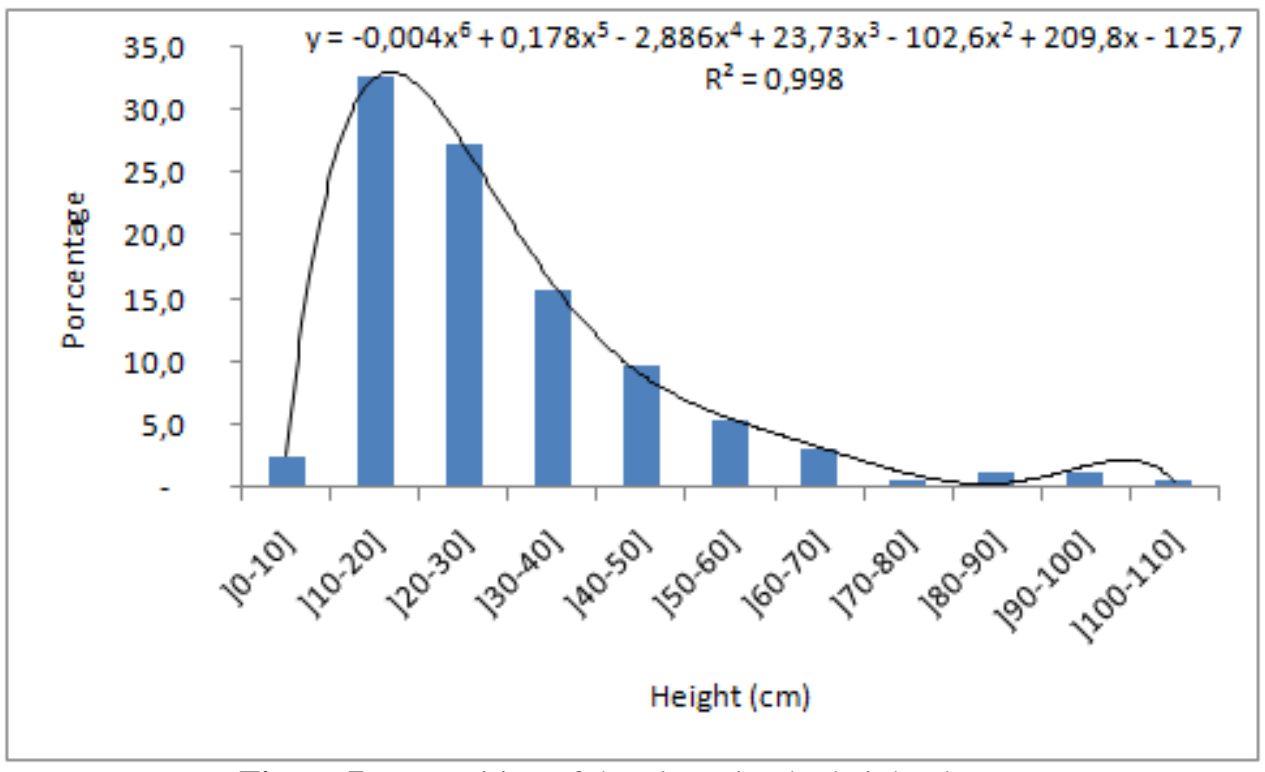

Figure 7:-Repartition of the plantation by height classes

The average height of the A. tortilis population is $28.9 \mathrm{~cm}$. The distribution of height classes is unimodal $($ mode $=$ $10-20 \mathrm{~cm}$ ) (Fig. 8). It shows that individuals less than $50 \mathrm{~cm}$ tall predominate $(81.1 \%)$. This indicates that most individuals are small. These values are quite comparable to plantation averages.

The trend line that better expresses the population distribution of A. tortilis is a polynomial (polygonal) function of degree 6.

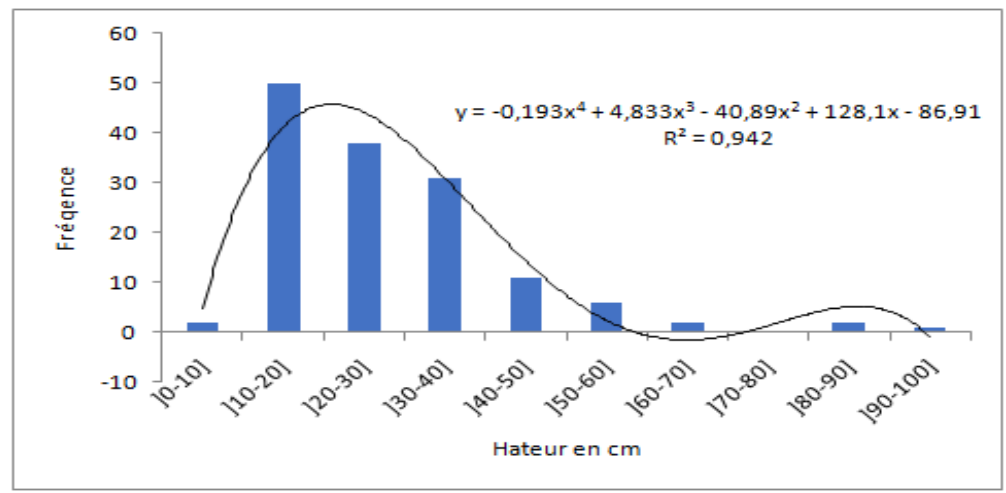

Figure 8:-Distribution of the population of A. tortilis by height classes

The average height of the Prosopis juliflora population is $46.43 \mathrm{~cm}$. The distribution of height classes is unimodal $($ mode $=20-40 \mathrm{~cm})($ Fig 9).

The trend line that better expresses the population distribution of Prosopis juliflora is a polynomial (polygonal) function of degree 5 . 


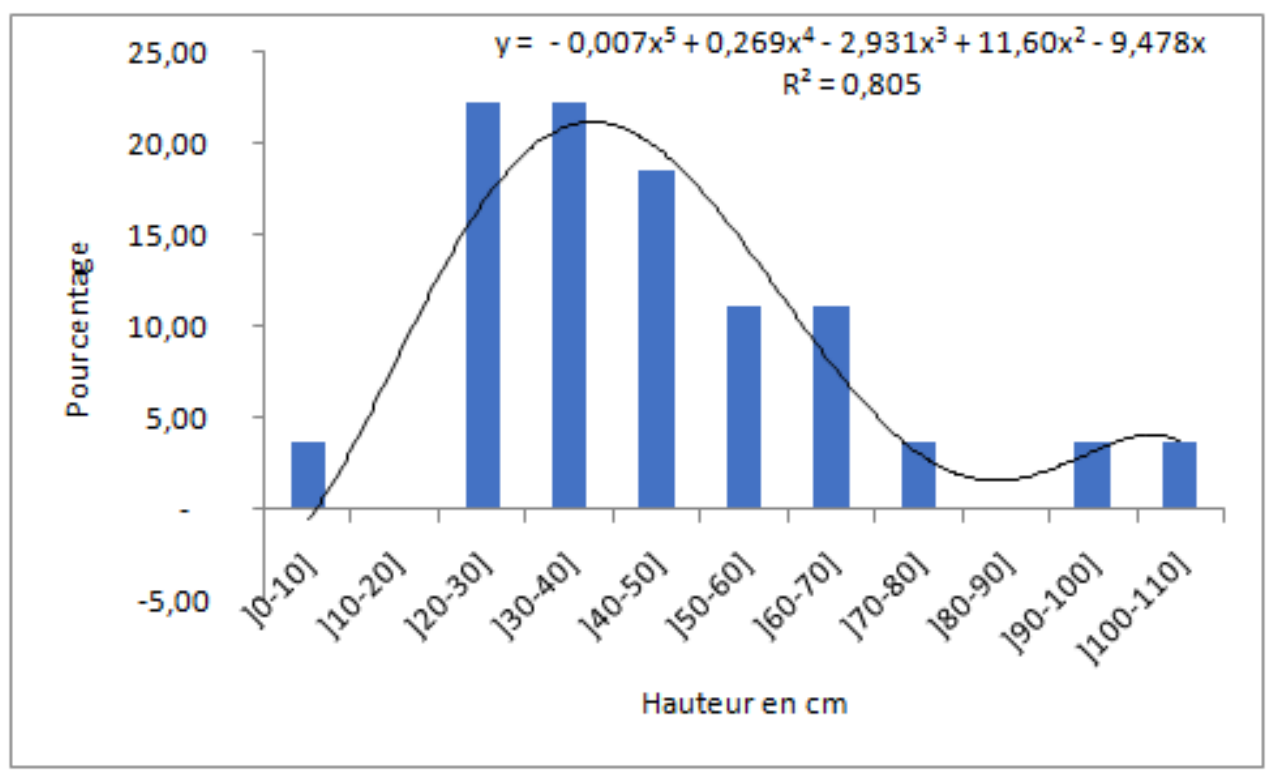

Figure 9:-Population distribution of Prosopis juliflora by height classes

The population structures of $P$. juliflora and A. tortilis show the distribution of species according to their size in the plantation. They are essential for studying the growth dynamics of these species. In an even-aged plantation, the structure of the population has individuals that are distributed substantially according to Gaussian law, to give the graphical representation of a bell curve, the top of which represents the average tree ${ }^{[7]}$. This is not the case for population distributions of the two main plantation species with asymmetrical curves. The large disparity in the size of the trees is certainly linked to the high mortality of the plants. Asymmetrical structures reveal a lack of plantation monitoring ${ }^{[7]}$, these interventions should have contributed to improving tree growth.

In general, over the years, there is a reduction in the number of stems in small diameter classes in favor of higher diameter classes, which is a normal process in forest plantation.

\section{Size distribution of plants:-}

The demographic structure of the plantation was determined by histograms of the distribution of individuals according to their distribution by diameter classes. The histogram is established with the abscissa classes diameter and the ordinate of the percentage corresponding to each class. We considered the same amplitude of diameter classes $(3 \mathrm{~mm})$ for all species although this value does not have the same meaning for all species ${ }^{[8]}$.

Plantation distribution by diameter class (Fig 10) has a unimodal distribution (mode $=3-6 \mathrm{~mm}$ ), with a predominance of individuals of the classes3-6] (41.9\%) and ]6-9] (24.6\%), which alone account for $66.5 \%$ of inventoried individuals. The average circumference of the plantation is $6.79 \mathrm{~m}$. Most plants have a circumference less than or equal to $9 \mathrm{~cm}(71.2 \%)$.

The plantation distribution by diameter class adjusts to a polynomial function of degree 4 . 


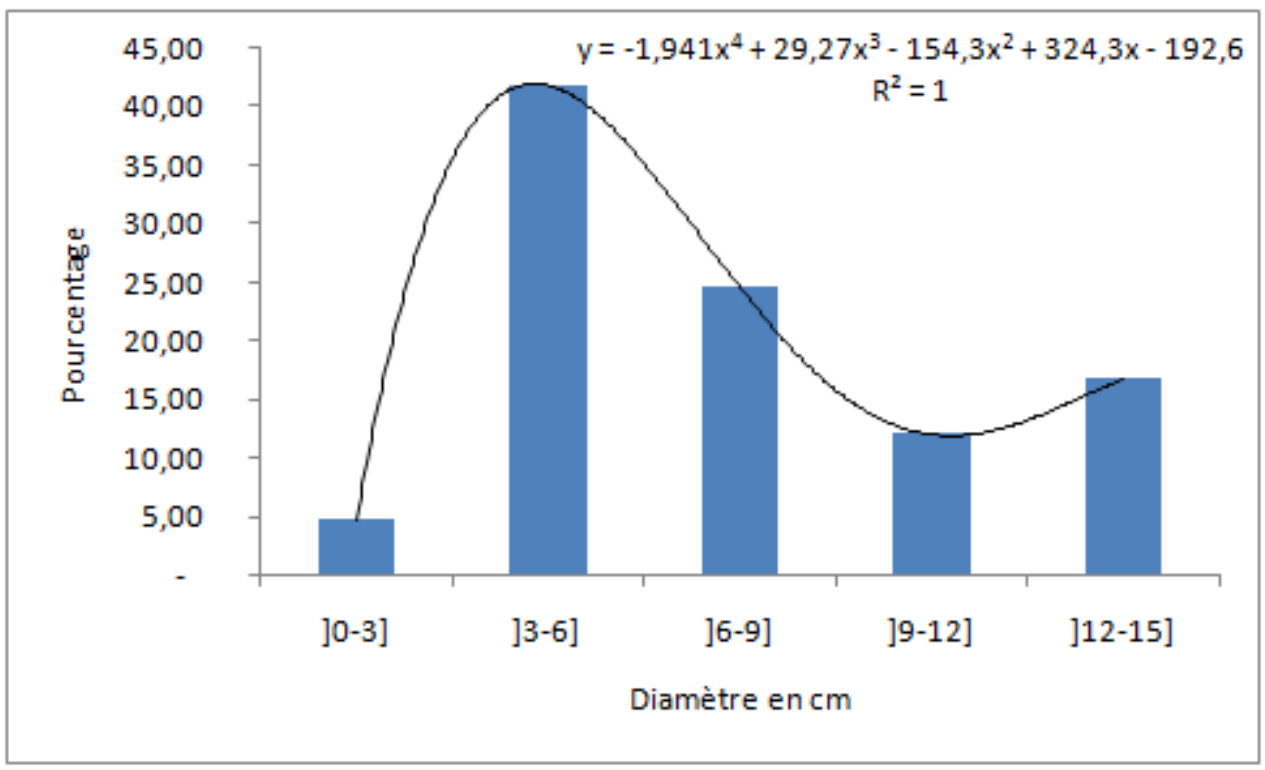

Figure 10:-Plantation distribution by diameter classes of stems.

The diameter class distribution of the Acacia tortilis population is shown in Figure 11 with a bell-like shape, centered on the circumference class (3-6 $\mathrm{mm}$ and 6-9 $\mathrm{mm}$ ). The distribution of this population is unimodal (3-6 $\mathrm{mm}$ mode) with an average circumference of $6.77 \mathrm{~mm}$.

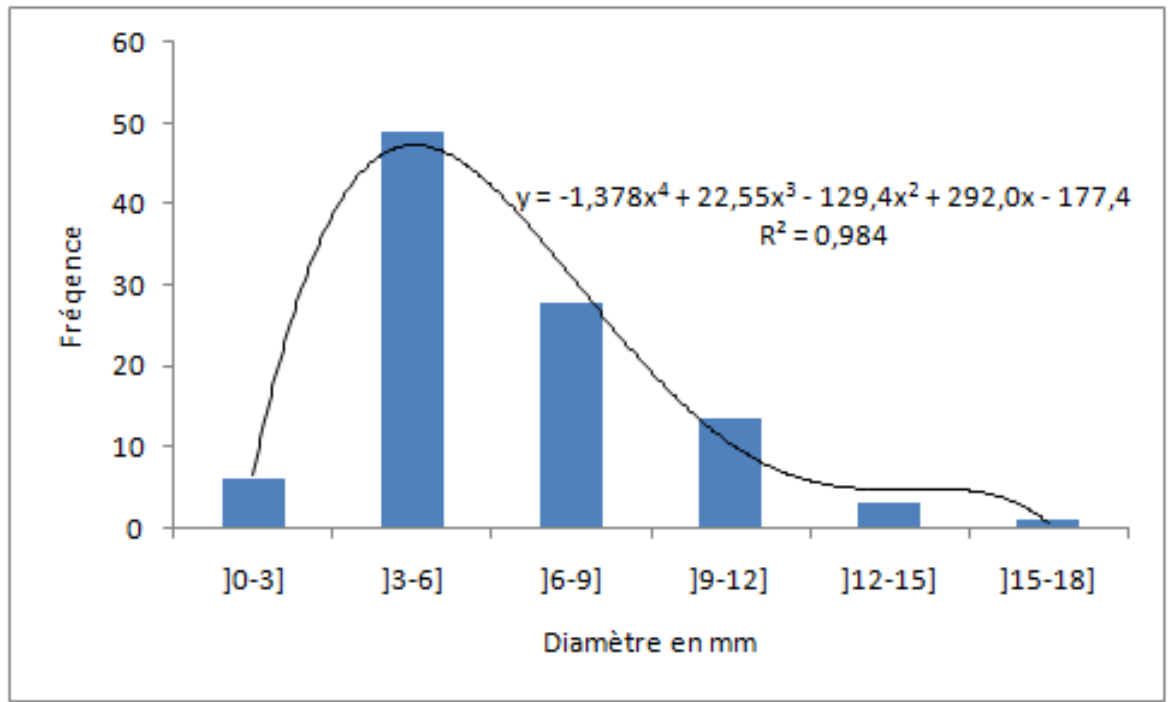

Figure 11:-Population distribution of an Acacia tortilis by diameter class

\section{Conclusions:-}

The success of plantations depends on many factors, some of which are related to the physiology of plants and others to the specific characteristics of the physical environment (climatic conditions, frequency of watering, etc.). Species with a high survival rate and a low proportion of mortality are those that are better adapted to the planting site. Thus, the species that seem to be best adapted are:Acacia tortilis and Prosopis juliflora showed higher performance than other species tested for both survival and growth (size and diameter) after one year of planting. Among the criteria studied, the principle of survival is chosen as the main criterion of tolerance of species to environmental conditions. With a survival rate of over $50 \%$ after one year of planting, the success of Benichab's plantation is assured. As for growth, it is satisfactory despite climatic constraints. These useful results for the study of dynamics show the need to set up a simple monitoring system to assess plantation dynamics. In an arid 
environment like Benichab where climatic conditions are severe, the choice of species is decisive. Thus, in the current context, we recommend Acacia tortilis as the main species to which we can associate other native species on which the study of the propagation conditions is in progress. These are: Ziziphus lotus, Acacia ehrenbergiana, Hammada scoparia, Maerua crassifolia and Capparisdeciduaswhich would be well adapted to the environmentand can provide a variety of ecosystem services.

\section{Acknowledgments:-}

The authors would like to thank the following people for their support, advice, input, and review of sections of this project: Diwen and Atifa."

\section{Bibliography:-}

1. Lafdal M. Y., Soule A. (2017) Benichab EBA sites updated restoration protocol MEDD 13 pages

2. Kone, K. H. C., N. K. M. Boraud, A. E. Issali, et A. K. Kamanzi. «Influence du mode de plantagesur la survie et la dynamique de croissance des stumps de teckutilisésdans les reboisementsindustriels en zone de forêt dense semi-décidue de Côte d'Ivoire ». J. Applied Biosciences 32 (2010): 1956-1963.

3. Bekker K., Rance W., Monteuis O., 2004- Teak in Tanzania: II. The KilomberoValleyTeakCompany. Bois et Forêt des Tropiques 279:11-21

4. Rabiou H, Diouf A, Bationo B. A., Segla K N, Adjonou K, Kokutse A D, Radji R, Kokou K, Mahamane A. et Saadou M. (2015)Structure des peuplementsnaturels de PterocarpuserinaceusPoir.dans le domainesoudanien, au Niger et au Burkina Faso. Bois et forêts des tropiques, 2015, nº 325 (3) PP 71-83

5. Abdourhamane H, Rabiou H., Diouf A, Morou B., Mahamane A. et Bellefontaine R. (2017) Structure démographique et répartitionspatiale des populations de Sclerocaryabirrea (A. Rich.) Hochst. dusecteursahélien du Niger. Bois et forêts des tropiques, 2017, $\mathrm{N}^{\circ} 333$ (3) PP 55-66

6. Landman G. (1988) Comment apprécier la vitalité d'un arbreou d'un peuplementforestier?R.F .F . - XL - 4-1988 PP 265-284.

7. Ngueguim J. R., Zapfack L., Noiha N. V., Onana D., Betti J. L. et Riera B. (2015) Expériencessylvicoles au Cameroun : Croissance, mortalité et adaptabilité des espèces de bois d'oeuvre dans la station forestière de Mangombé (1964 - 2010)Int. J. Biol. Chem. Sci. 9(6): 2789-2807.

8. Akpo L. E. et Grouzis M. (1998) Influence du couvertligneuxsur la diversitéspécifique de la végétationherbacéedans la forêtclassée de Bokor (Haute Casamance) AAU, Reports 39 : 169-181

9. Soule A. (2011) Des caractéristiquesécologiques de Ziziphus mauritianaLam. dans le Sud mauritanienThèse de Doctorat de troisième cycle UCAD Dakar 104 pages. 